\title{
BMJ Open Attitudes and beliefs of Spanish families regarding their family members aged 75 years and over who live alone: a qualitative study
}

\author{
Jesús Molina-Mula, ${ }^{01}$ Julia Gallo-Estrada, ${ }^{1}$ Alexandre Miquel-Novajra ${ }^{2}$
}

To cite: Molina-Mula J, GalloEstrada J, Miquel-Novajra A. Attitudes and beliefs of Spanish families regarding their family members aged 75 years and over who live alone: a qualitative study. BMJ Open 2019;9:e025547. doi:10.1136/ bmjopen-2018-025547

- Prepublication history for this paper is available online. To view these files, please visit the journal online (http://dx.doi. org/10.1136/bmjopen-2018025547).

Received 6 August 2018 Revised 28 February 2019 Accepted 8 March 2019
Check for updates

(C) Author(s) (or their employer(s)) 2019. Re-use permitted under CC BY-NC. No commercial re-use. See rights and permissions. Published by BMJ.

${ }^{1}$ Department of Nursing and Physiotherapy, Universitat de les Illes Balears, Palma de Mallorca, Spain

${ }^{2}$ Department of Social Work, Universitat de les Illes Balears, Palma de Mallorca, Spain

Correspondence to Dr Jesús Molina-Mula; jesus.molina@uib.es

\section{ABSTRACT}

Objective This study aimed to assess the attitudes and beliefs of Spanish families regarding their elderly family members aged 75 years and over who live alone, with consideration of gender and educational differences among the family members.

Methods This qualitative study was based on the critical social paradigm, the theory of constructivist structuralism and Bourdieu's theory of sociology of action. Four discussion groups were created with the following distribution of family members based on their gender and educational level: women with higher education, women with basic or secondary education, men with higher education and men with basic or secondary education. Participants were selected using purposive and snowball sampling. Announcements inviting voluntary participation were posted at primary health care facilities, social centres and neighbourhood associations in Mallorca, Spain. Results Analyses of the group discussions and a field journal revealed that families believe that elderly individuals prefer to live alone to retain their freedom and individual identities.

Conclusions Families held two main views regarding elderly individuals living alone: a more traditional one in which elderly care is considered a moral duty associated with women, and a more modern view in which elderly care is considered a personal option that can be delegated. Sociomedical resources were considered insufficient and not easily accessible.

\section{INTRODUCTION}

Population ageing is a major phenomenon. Projections from a review by the United Nations expect the world population of individuals aged 60 years and over to triple by 2050 , growing from 600 million to 2 billion. The most notable increase in the number of individuals aged 60 years and over is expected in developing countries, increasing from 400 million to 1.7 billion. ${ }^{1}$ However, population ageing is not uniform worldwide. In European countries, Canada and the USA, population ageing is expected to accelerate when the baby boomer generation reaches the age of 65 years.
Strengths and limitations of this study

- This study revealed that both the traditional discourse of elderly care that considers it a moral duty associated with women and the more modern discourse that considers elderly care as a responsibility that can be delegated are in use.

- It was found that the healthcare system needs to adapt its care policies on dependence to the concerns of families and users.

- The results suggest that the needs of families should be considered by health managers in order to offer sufficient resources for the care of elderly individuals living alone.

- Research on other factors like an economic level that were not analysed in this study can broaden and deepen the understanding of the attitudes and beliefs of families regarding elderly care.

In Europe, according to data from the Statistical Office of the European Communities, ${ }^{2}$ individuals aged 65 years and over accounted for about $18.9 \%$ of the population in 2015. Spain is one of the most aged countries in the European Union; according to the municipal register of 2011 and the data collected by the National Institute of Statistics, the number of individuals aged 65 years or over was 8 million, which represents $17.2 \%$ of the population. An important characteristic of population ageing is the increase in the population of the oldest old. By 2050, forecasts expect that one out of five individuals currently aged 60 years or over will be aged 80 years or over. ${ }^{1}$

Ageing is accompanied by a rise in health problems that can make it difficult for individuals to carry out their daily life activities independently. The burden of these problems continues to be borne by the family. However, in northern European countries, it is considered the state's responsibility to look after dependent individuals, whereas 
in southern European countries, it is viewed as a family responsibility. ${ }^{3}$

According to de Ussel, ${ }^{4}$ in Spain, the true 'social affairs ministry' is the family; the family helps with illnesses, raises children, takes care of elderly family members and provides support in times of need. The family even provides support and care to hospitalised relatives. Yet, clearly, this care is not shared equally between all family members, with men only slowly becoming involved in care responsibilities. ${ }^{56}$

In caring for the elderly, when factors related to gender cross with those related to class, the 'double biography' of Spanish women is intensified. On the one hand, more traditional women who do not work outside the home and have fewer economic and educational resources take on the role of a double caretaker (of the home and family), but on the other hand (and increasingly more so), professional women with more resources spend less time devoted to the home and dependent individuals. This phenomenon is produced in parallel with a social change in family relationships and in how individuals deal with caring for elderly individuals.

According to Martín, ${ }^{7}$ family relationships, especially those between children and parents, involve commitments based on modernity (individualism and preservation of freedom) and tradition (unconditionality and obligation). This finding reveals the decreasing tendency of elderly individuals to prefer family. ${ }^{8}$ Faria $e t a \theta^{\theta}$ examined the intergenerational differences that influence the type of care provided by family members to their dependents. The authors reported differences in the understanding of the concept of care and the responsibilities assumed by each family member. Furthermore, the larger the differences in age between relative caregiver and elderly, the more care services were contracted for their care.

A study by Ayalon ${ }^{10}$ analysed the discourse of older people and their adult children with regard to old age and ageing. The author observed that the elderly considered the care of elderly family members to be a responsibility, whereas the children believed that the care of care of elderly family members was no longer as much of a responsibility and they preferred to hire services for care. This finding is evidence of a generational paradigm shift in how care for the elderly is understood.

The number of elderly individuals living alone is increasing steadily, but this fact does not necessarily imply that these elderly individuals are living autonomously. Disability is not uncommon in single-person households. ${ }^{11}$ One of the most important factors that make it possible for elderly individuals to continue living alone is their family and social relationships. Therefore, even though they no longer live with their children, elderly individuals living alone still have care needs, and in many cases, they have family support. These elderly individuals prefer to live alone, with families often establishing a 'close' relationship without living together. This phenomenon is known as 'intimacy at a distance', ${ }^{12}$ p. 108). Understanding the attitudes and beliefs of families regarding this living situation is important for identifying the nature of support required for elderly individuals living alone.

Wilson ${ }^{13}$ found that in this type of relationship the family often limits the freedom of the elderly individual; the children are very controlling, opposed to change, and tend to disapprove of activities that may involve risk. Yet, despite the social and economic pressures that dominate family life, in Europe, intergenerational solidarity among families is maintained. ${ }^{14}$ Walker et $a l^{15}$ interviewed 23 families of elderly individuals who lived alone and found that the latter were somewhat resistant to being helped by their family members. Furthermore, it was found that elderly individuals who lived alone experienced isolation in certain times of need due to a lack of access to effective communication channels between themselves and their family members.

The present study aimed to assess the attitudes and beliefs of families regarding their family members aged 75 years and over who live alone, with consideration of gender and educational differences among the family members. Caring for elderly individuals facilitates growth by: (A) bringing dignity to the care process; (B) including, elaborating on and teaching about the life cycle; (C) diminishing the gap between theory and practice of end-of-life care; (D) identifying new values; and (E) creating a multidimensional environment that promotes positive individual, family and social experiences in the ageing process. ${ }^{16}$

We employed Pierre Bourdieu's theoretical perspective. Bourdieu opens up a new field of possibilities for understanding the influences of social roles and status on elderly individuals' preference to live alone. Although this study belongs to a broader one that analyses the factors that determine the permanence at home of elderly people living alone, this work explores the beliefs and attitudes of families regarding their family members aged 75 years and over who live alone, with consideration of gender and educational differences among the family members.

\section{MATERIALS AND METHODS}

This study employed a qualitative methodology that assumes an open listening position to social discourse. The study was based on the critical social paradigm, guided by the theory of constructivist structuralism and the concept of sociology of action from the theoretical approaches proposed by Bourdieu. ${ }^{17}$ This methodology helps to construct categories of analysis that can account for the existing social discourse. Additionally, this study followed the recommendations of the Standards for Reporting Qualitative Research.

The critical social paradigm considers that social structures can be a source of oppression for some social groups. ${ }^{18}$ This study attempted to derive an approximation of the evolution of the family structure to understand the nature of the social support available. Additionally, 
this study attempted to identify the unmet support needs of elderly individuals.

Bourdieu's theory helps us to understand the experience of loss of autonomy that is partly inherent to ageing. According to this theory, loss of autonomy produces a disposition in terms of symbolic capital that leads to the occupation of a low position in the social space, which in turn limits the possibilities of manipulation of the physical space and the body itself. The domination of individuals is therefore inscribed in a structure that reproduces the conditions required to maintain their status through the predispositions that guarantee it. ${ }^{19}$

Bourdieu analysed the influence of cultural goods on the differentiation of individuals into classes. Accordingly, level of education, social class and gender are considered to allow the prediction of an individual's adaptive capacity. ${ }^{19}$ For this reason, the research focused on gender and level of education in the selection of participants.

\section{Participant selection}

Family members of elderly individuals aged 75 years and over who were living alone in Mallorca, Spain, participated in discussion groups. Four discussion groups were organised, comprising 18 women and 15 men aged between 33 years and 68 years, who directly cared for or were the person of reference for elderly individuals aged 75-99 years.

To meet the proposed aims of the study, the discussion groups were created based on gender and level of education, as these variables show a differential effect on the perception of autonomy in the home. The distribution in the discussion groups was as follows: women with higher education (WHE), women with basic or secondary education (WBE), men with higher education (MHE) and men with basic or secondary education (MBE). According to Bourdieu (2000), culture shapes individuals through gender, which in turn affects the perception of everything else.

The inclusion criteria for the selection of participants were as follows: (A) being a woman or a man with basic or secondary education, or higher education (from start of university studies and including basic and media studies), (B) being a relative of an elderly individual aged 75 years or over, (C) having any family relationship with the elderly individual and (D) the elderly individual had been living alone for more than 6 months.

It is worth noting that these family members were the first generation to experience massive incorporation of women into the job market outside the home, to belong to smaller families and whose family members were more geographically scattered, all of which are determining factors of the task of caring for a family member. The need for care stems from the need to protect the vulnerable. It is based on the notion that family health is measured by the family's ability to cope with the problems of its members. ${ }^{19}$

In order to acquire participants, announcements were posted at primary healthcare centres, social centres and neighbourhood associations to attract volunteers. Subsequently, volunteers who showed interest were selected using snowball sampling, according to the inclusion criteria mentioned above.

The participants personally received an informed consent form with a study information sheet, which included the details of the study objectives, data collection methods and their rights regarding the protection of their personal data. The discussion group was scheduled once the participants had signed the informed consent form. It was conducted at the authors' university. All sessions were audio recorded. Once transcribed, the audio was destroyed, and all data were deidentified. In the process of triangulation, the participants checked whether the transcripts and codes created corresponded to what they had said.

\section{Data analysis}

Discourse analysis was used to explore the life contexts of the participants from Bourdieu's theoretical perspective. ${ }^{17}$ According to this perspective, old age is characterised by social constructions that influence the ways in which individuals understand their relationships. Discourse analysis is a qualitative analysis of discursive coherence (spoken and textual) in a certain social context, where the individual's use of language is considered to have constructed different versions of this social context. ${ }^{20}$ It explores how expressions are used according to the resources and functions of each group member. The data analysis consisted of interpreting the transcripts and their implied significance. Accordingly, systematisation was established that constituted the basic analytical process through data reduction, data disposition and transformation, and subsequently obtaining results and verifying conclusions. ${ }^{21}$

Discourse analysis allows the researcher to focus on the meanings of the participants' communication and to interpret these meanings in light of sociocultural influences and customs. ${ }^{22}$ The present study examined family members' perceptions about their elderly family member who lived alone, by interpreting their use of language and the meanings expressed. In addition, this discourse analysis encouraged the researcher to focus on the meanings transmitted by the participants and identify hidden and implicit discourses in their modes of description, explanation and interpretation. ${ }^{22}$

The use of language was defined as a functional and deliberate action. The human being chooses language as a mode to describe social norms. These norms are a part of cultural determination. Subsequent approaches advance from the consideration of 'sociolinguistic interactions', through the 'ethnography of communication', to the 'pragmatic' and 'variations of analysis'. ${ }^{23} 24$

The systematic analysis conducted in this study involved the following steps or phases ${ }^{25}{ }^{26}$ : (1) obtaining information through systematically recording field notes and documents pertaining to the discussion groups; (2) capturing, transcribing and ordering information, 


\begin{tabular}{ll} 
Table $1 \quad$ Transcription techniques used \\
\hline Element & Transcription notation \\
\hline Silence $>3 \mathrm{~s}$ & (Silence) \\
Silence $<3 \mathrm{~s}$ & $\ldots$ \\
Laugh & (Laugh) \\
Laughter interviewer, & (All laugh) \\
interviewee and observer & \\
Accounts & Literal transcription \\
Doubtful attitude & (doubt) \\
\hline
\end{tabular}

including electronically recording (recording in digital format) the discussions; and (3) coding the information in order to group the data into categories based on the ideas, concepts or similar topics discovered by the research team. Codes are labels that allow units of meaning to be assigned to descriptive or inferential information compiled during a study. The grouping and unfolding of the condensed pieces provide a basis from which to draw conclusions. Additionally, the researchers and their team maintained a field journal as part of the reflexive process and to record observations made during the meetings.

Methodological rigour was achieved by maintaining the field journal. The steps and decisions involved in conducting the discussion groups were described in the journal. The discussion script was developed based on the objectives of the study and the thematic categories that emerged during the literature review. Various tactics, such as facilitation/animation, reaffirming and repeating questions, clarification of the concepts asked and recapitulation, were used to collect rich data. The transcription included notations to represent silence and other aspects of the discourse (table 1).

The triangulation process consisted of the delivery of transcripts of two discussion groups to each member of the research team and subsequent discussions on the same through three meetings. It began with an initial inductive analysis without pre-established categories or codes, although the topics described in the literature review and the objectives of the study were considered as references. We then decided on certain categories that encompassed these discourses, and an approximation of the codes for each category was made according to the different discursive positions. The comments collected increased the methodological rigour of the research and provided key elements for subsequent categorisation of the data.

Next, the refined and sensitive discourse analysis phase began. This process allowed the division of each code into different discursive positions on the phenomenon being studied, as well as the configuration of a series of relationships (associations, causal and transitive) between the different codes based on the factors determined by previous studies on this topic.
Table 2 Sociodemographic characteristics of the discussion groups

\begin{tabular}{llll}
\hline $\begin{array}{l}\text { Discussion } \\
\text { group }\end{array}$ & Gender & Educational level & Participants \\
\hline 1 & Female & $\begin{array}{l}\text { Basic or secondary } \\
\text { education }\end{array}$ & 10 \\
\hline 2 & Female & $\begin{array}{l}\text { Higher education } \\
\text { Basic or secondary }\end{array}$ & 8 \\
\hline 3 & Male & $\begin{array}{l}\text { education } \\
\text { Higher education }\end{array}$ & 10 \\
\hline 4 & Male & High & \\
\hline
\end{tabular}

Following the above-mentioned processes enabled us to meet the criteria used to assess the methodological rigour of our study. As suggested by Morse ${ }^{27}$ and Guba and Lincoln, ${ }^{18}$ these criteria include credibility, auditability and transferability.

This study was funded by the Spanish Health Research Fund (Fondo de Investigación Sanitaria) of the Carlos III Health Institute, which reports to the Spanish Ministry of Economy and Competitiveness (PI09/90248). This study complied with the Ethics Code of Good Practice for health research and current legislation in terms of confidentiality of data. Informed consent was obtained from all participants before the commencement of the study.

\section{Participant involvement}

The participants (family members of elderly individuals aged 75 years and over and living alone) were involved in the development of the interview script, the discussion groups and the triangulation of the results. With regard to the triangulation of the results, some participants reviewed the transcriptions of the groups and the codes and categories for accuracy.

\section{RESULTS}

A total of 40 participants were divided into four discussion groups based on gender and educational level. The WBE group consisted of 10 women, the WHE group consisted of 12 women, the MBE group consisted of 8 men and the MHE group consisted of 10 men (table 2).

\section{Sociodemographic profile of family members of individuals aged 75 years and over who live alone}

Participants in the WBE group were aged 33-68 years. Their educational levels included high school and vocational training. Their professions included administrative service, housewife, hospitality (unemployed), clinic assistant, yoga instructor and cook. They were the primary family members responsible for the care of individuals aged 77-99 years. The relationships with the individuals they cared for were daughter, aunt, friend, mother-in-law and father-in-law. The elderly individuals had lived alone for 3-18 years. The family members considered the level of autonomy of the elderly individual they cared for as the following: 'fairly dependent', 'partially 
dependent', 'mildly dependent', 'autonomous' and 'very autonomous'.

Participants in the WHE group were aged $37-58$ years. They had completed degrees in psychology, law, pedagogy, philology, nursing or teaching. They practised as a psychologist, nurse, civil servant in an autonomous community, professor, lawyer and linguistic advisor. They were the primary family members responsible for the care of individuals aged 75-88 years. Their relationships with the elderly individuals they cared for included mother, aunt, father and mother-in-law. The elderly individuals had lived alone for 3-32 years. The family members considered the level of autonomy of the elderly individual they cared for as the following: 'high', 'needs partial help', 'has typical age-related losses' and 'has symptoms of dementia'.

Participants in the MBE group were aged $38-59$ years. Their educational qualification included administrative assistant training, professional training and undergraduate-level and graduate-level schooling. Their professions included caregiving professional, service sector, administrative service, actor, flight attendant and graphic designer. They were the primary family members responsible for the care of elderly individuals aged 75-87 years. For all these participants, the elderly individual they cared for was their mother, who had lived alone for 6 months to 24 years. The family members described the level of autonomy of the elderly individual they cared for with the following terms: 'pluripathology', 'mobility problems', 'is dependent', 'presents significant weight loss and pain' and 'has vision problems'.

Finally, participants in the MHE group were aged 37-59 years. They had degrees in music, philosophy, economics, physiotherapy, engineering, computer science and nautical sciences. They worked as a professor, fiscal adviser, industrial engineer, telephonist, electrician and bank employee. They were the primary family members responsible for the care of elderly individuals aged 75-89 years. The relationships with the elderly individuals they cared for were father or mother. The elderly individual had lived alone for 10 months to 20 years. The family members described the level of autonomy of the elderly individual they cared for as the following: "very autonomous', 'completely independent', 'independent', 'acceptable', 'has mobility problems' and 'is dependent outside the home'.

\section{Analysis of the categories and codes of the discussion groups}

In the following sections, we present the results of the analysis of the family discussions produced in the groups and the observations of the meetings to address the aims of this study. We also present examples of quotes from the aforementioned discussions.

To systematise the analysis in relation to the study aims, the groups were spatially located on two axes; the first was level of education to determine strategies related to delivering care and family members' experiences with the use of resources; the second was the types of families the participants belonged to, either traditional or modern, which could be related to the feelings of obligation or volition in delivering care. The main elements that described the attitudes and beliefs of family members regarding elderly individuals living alone fell into the following three main categories: (1) staying at home; (2) aspects of caring; and (3) use of social services and other resources.

\section{Staying at home}

The participants shared the opinion that elderly individuals prefer to live alone in their own homes, identifying the home as an area of freedom and power. Irrespective of educational level, they believed that if their elderly family member did not live alone, the elderly family member would not be able to fully preserve his or her autonomy and decision-making authority.

Family members of elderly individuals regarded the elderly individuals as survivors possessing strength and a sense of power that they wanted them to continue to have, even over the caregiver. Women in these families commented on the debate over the authority parents have had in patriarchal families, and they were aware that the parents wished to maintain that authority.

She doesn't want to have anything to do with anyone who could go into her house to take care of her.... When I've been in the house for over two hours, I notice that I'm disturbing her. (A participant from the MBE group)

The thing is, I think they don't want to leave their home; they would lose this status they have, of being in command. (A participant from the MBE group)

These family members perceived that the elderly individual preferred any sort of help that would enable him or her to continue living alone, as opposed to living with the family or living in an elderly care facility:

My mother... I think this thing of moving from her house-as well as wanting to live in her own home-I think what she is afraid of is being a bother, of not having her own place. (A participant from the MBE group)

For us, a home would be safer, but it's what she wants, to stay in her own home with her friends. (A participant from the MHE group)

These family members considered how staying at home called for carrying out changes to adapt to ageing and to ensure the protection of the elderly individuals both inside and around the home. Negotiating these changes was considered the best option, but negotiation was viewed as a challenge for the family members. Some measures entailed limits and loss of freedom for the elderly individual. A certain gap was also clearly observed between the times when the family and the elderly individual perceived a loss of physical autonomy and when they considered it necessary to initiate a new model of care. 
What you want to give your parents, which is also a benefit, even though they don't understand it like that, is when you have to go back to what I said before: negotiating, fighting, arguing. (A participant from the MBE group)

The difficult part is piecing together what we want and what they want. (A participant from the WHE group)

Elderly individuals and family members had different perceptions of the autonomy of the elderly individual. Family members considered preservation of age-appropriate mental and physical faculties essential to allowing the elderly individuals to continue to live alone.

I find that an individual can live alone when both their mental and physical faculties are good.... It is more important for them to be right in their head. (A participant from the WBE group)

Participants in the WBE group expressed concerns regarding the ability of the elderly individual to cope with potential risks. They believed that the elderly individual tended to minimise problems, overestimate his or her abilities and put off solutions. Therefore, these family members justified overprotective behaviours.

Those crafty comments of, 'since I'm self-sufficient and always have been very independent I'm going it alone ...'-that always gave her a lot of security. She felt good, they feel useful. (A participant from the WBE group)

She takes advantage of the opportunity to do all this when she's alone; when she's alone, I think, her [independent streak] comes out. (A participant from the WBE group)

However, participants in the MHE group focused on the freedom of elderly individuals to decide and assess their own abilities.

At 65, when my father died..., we had our first strong clash to understand what my mother could or was able to do living alone.... With her, we sorted out everybody: 'you do this, you the medical part, you the economic part, you the company'. (A participant from the MHE group)

You always have this worry, you often have to slow them down, because they think they're still 30 years old. (A participant from the MHE group)

When she got older and started having mobility problems, I also started wanting to control what she did and what she did not do. And she told me... 'I am your mother, and I have raised you, and I know perfectly what I must and what I have to do at every moment... I do not need you to control me...'. (A participant from the MHE group)

Families expressed concerns about the future, including concerns about threats to the elderly individual's ability to continue to live alone and concerns about related changes in the family's involvement as caregivers.

I know he [my father] is 85 years old and is not getting any better [but] getting worse, and then yes, thinking about this situation does make me very anxious. (A participant from the WBE group)

I'm afraid he will get ill, that [he'll have to be taken] out of his environment, [detached]. (A participant from the WHE group)

\section{Aspects of caring}

The families commented on the impact of social and family networks on the disabilities of the elderly individual. Sharing tasks among the caregivers, according to the needs of the elderly individual, made it easier for the elderly individual to continue to live alone.

I was able to make two of my four siblings understand that they had to collaborate with me. (A participant from the MBE group)

Among family members who considered caregiving a moral duty, the caregiver was usually a middle-aged housewife. For these family members, isolation of the elderly individual was considered a sign that they had neglected their duty as children, consistent with the discursive position of a social group within a traditional social structure with a subordinate role of wife and daughter, which makes it difficult to set limits. Simultaneously, in continuity with the patriarchal model, the most conservative elderly individuals attempted to and continued to be authoritarian, making the family feel guilty if they had not looked after them.

Being worried sick, I shut the door to her house, and anguish came over me. You feel guilty.... I was very protective of my mother; my mother didn't need so much protection.... She lives to a certain extent the way she wants to. (A participant from the WBE group)

I go every day because otherwise I also suffer, then my aunt too, then I also have my mother-in-law ...; but things are going well, so I'm fine. (A participant from the WBE group)

In contrast, some family members held a discursive position along the lines of present-day family relationships, slightly separate from the sense of moral duty, but with an implementation of strategies that cushioned the effect of age-related problems. They did not consider caring as an obligation but tended to share the load with other family members, hire services and set limits.

I get a call during the night. [My parent says,] 'tomorrow you'll come and give me my pills'. I ask, 'hasn't L. been there?' That's my brother, and [my parent] says 'yes'. I ask, 'why didn't he get your pills ready?' and [my parent] says 'you come, you get them ready, you always get them ready for me'. (A participant from the WBE group) 
Some siblings make a forced visit and others like me, I call my father [and ask] 'Are you alright? Do you need anything?' because I know what I'm doing is to try and respect him. (A participant from the MHE group)

However, concerning the discourse of work as a seemingly immovable activity in the life of men and women, which affects care, we saw an emergence of discourses consistent with the need to reconcile work and family life.

The luck I have had since my father died, I have been able to reduce my work to only $75 \%$; then, every month, I have a week I don't work. (A participant from the MBE group)

You can't look after your mother well, you can't look after your children well, your house, your leisure; in other words, everything, coping with everything well is really hard. You always have to neglect one thing more than another. (A participant from the WBE group)

All participants considered it essential to have the support of other individuals in delivering care. Women looked for support mainly in the family, while men looked for support in the family and in hired caregivers. Uneasiness regarding the criteria for sharing the load was a frequent topic in the discussions.

In my house, for instance, it would mean being alone from morning to evening. In my sister's house, it would mean being just as alone.... Work is work, and you also need to have a person who can help you. (A participant from the MBE group)

It affects your children, your husband, your work; it affects everything, and until the time comes when your head says, 'M., you can't carry on like this', it's just that it's you next. (A participant from the WBE group)

A consensus was observed among the participants concerning the idea that elderly women adapt better than elderly men to living alone. Likewise, the participants considered women to be less demanding care recipients. The participants also declared that if it was necessary to live together, they believed the process would be easier with elderly women than with elderly men.

Men, I think they're more complicated than women [laughter]. I can take my mother into my home, but I think it's easier to talk to them [women]. (A participant from the MBE group)

She's been a widow for a few years. If it were the other way around, I would have had my father living with me for a good few years. (A participant from the MHE group)

We also found evidence of the existence of an asymmetric distribution of power (and its relationship with demands) between the caregiver and care recipient, depending on gender and family ties. The elderly individual makes different demands on each relative according to specific criteria, some of which are based on gender.

She asks me to do some things, she asks my brother to do other things, the same way as $\mathrm{s} /$ he asks my sisters to do others. (A participant from the MBE group)

My mother ask[ed] me, 'Are you leaving again? and for a week! Who will take care of the children?' But when [it was] my brother who [had] to leave ...? She said, 'That's good, poor thing, because with the amount of work he does'. [laughter]. (A participant from the WBE group)

Participants believed that the gender of the caregiver made a difference in their involvement in delivering care. Women, rather than men, expressed the weight of the duty to care for their children and to care for their elderly parents. Although the request for help on behalf of the elderly individuals is based, in part, on the trust that exists between them, the respondents pointed out that elderly individuals demanded less from male caregivers and from those who have a family.

[I asked], 'What are we going to do with Mum?' I stood firm, and I said, 'You, do you want her in your house?' 'No, because I'm a widower'. My sister-in-law said to him, 'If you want her, you're coming to live here with your mother'. She said to me, 'And you?' I say, 'No..., I'm not going to give up my life to look after my mother.... When the time comes, we'll see'. (A participant from the WBE group)

My mother says that the child cannot be asked to take care of her because he is always working and has to take care of the woman and the children. What about me? I do not have children, I do not have a husband, I do not have a house, I do not have to work? (A participant from the WBE group)

\section{Use of social services and other resources}

Participants recognised the improvement of some sociomedical resources offered by the Spanish national system of services. However, they were critical of the bureaucracy involved in applying for services and considered the services provided to be insufficient to cover their needs. Some confusion was seen among families when faced with the lack of coordination among the different professionals involved.

We had a nurse with him because we were unable to know what we had to do... place a person inside the house, if it is absolutely necessary. (A participant from the MBE group)

[The resources] are few and far between, and they make things very hard for you ... I think the day will arrive when rather than setting up kindergartens, eh, they'll have to set up day care centres for the elderly. (A participant from the WHE group) 
Some participants considered that new technologies to be underused, partly because elderly individuals associate technology with complexity and partly because of the technology gap and lack of devices adapted to their abilities.

My mother has a mobile phone with a button that she presses and dials, and I have made her aware of the need to never forget her phone. For all intents and purposes, she is less alone now than before when she used to live with my father... As soon as she calls me, I can arrange assistance. (A participant from the MHE group)

The care centre ... my mother told my sister to put on the collar (telecare) herself... I also gave her a mobile phone, but there was no way she could manage it [or] a laptop. She's attended a couple of courses, but digital technology—no way. (A participant from the MHE group)

Nursing homes emerged as an alternative to an elderly individual's own home. The participants held several opinions with regard to nursing homes, including opinions on the appropriate destination for dependents, the confusion around the negative connotations of nursing homes and nursing homes as the ultimate option despite the elderly individual's feelings of abandonment by the family. The participants' negative perceptions of nursing homes are consistent with the views portrayed in the media, which often depicts nursing homes as places to visit but not to live. Placing a family member in a nursing home is seen as abandonment; however, if it were necessary, the family would not hesitate to take the elderly individual into their own home. They felt the duty of care was met through this solution, independent of who would take up the caregiving responsibility and how it would be done. In fact, when working hours conflicted with the demand for care, rotating among children's homes was considered. Living with the family in these cases does not prevent isolation or the need to hire a home care services provider.

For her, of course, it's unthinkable to go into a home.... She says she'd rather die.... She usually says she hasn't had four children to end up being taken to a home. That's also true!. (A participant from the WBE group)

Entry into a home depends quite a lot on how they see themselves.... There may be some resistance, but in the end, they accept the situation. In my aunt's case, her entry into a home was from the hospital..., with my promise that if she got better and strove to improve, she would go back to her own home. (A participant from the MHE group)

\section{DISCUSSION}

This study examined the attitudes and beliefs of families regarding their elderly family members aged 75 years and over who live alone, with consideration of gender and educational differences among the family members. The impact of changes in the family on the care of elderly individuals is well known. ${ }^{28-31}$ Although the idea that elderly individuals prefer to live alone rather than with their families is commonly known, ${ }^{4814}$ this study's examination of the underlying structures of this living situation found that the actions and relationships related to the elderly individual's living alone notably modified the actions stemming from the habitus of this generation of elderly individuals. A survey by Boldy $e t a l^{32}$ of 3050 individuals aged 50-75 years examined the factors that affect elderly individuals' preference to live alone and found similar results.

Families interpret their elderly family members' choice to live alone as an effort to retain the ability to make their own decisions and, to a certain extent, their power and believe that these individuals may interpret the loss of the habitus connected to where they have led important parts of their lives as giving up. ${ }^{17}$ Over the years, elderly individuals grow to appreciate the freedom that their own homes give them, and occasionally they come into conflict with their families, who tend to overprotect them. The home is considered a space of resistance where one wants to live the rest of his or her life. This was also found in other studies where the home is considered a space that provides autonomy, comfort and good quality of life. In addition, the location of the home determines accessibility and social networks. Most individuals prefer to receive assistance at home than to have to leave the home for assistance. ${ }^{32}$

There is a clear gap between the elderly individuals' perception of his or her abilities and their family's perception. Elderly individuals tend to minimise their difficulties and consider themselves capable, whereas the family, especially women, focus on the risks involved in living alone. ${ }^{1133}$ In short, the permanency of an elderly individual continuing to live alone revolves partly around the social network that they rely on in difficult situations. These aspects were also found in the study by Ayalon, ${ }^{10}$ which described the factors of permanency in the home as: (A) family members' expectations regarding physical autonomy, (B) the concept of old age and (C) the responsibility to accept care.

In a traditional family that is based on the patriarchal model, the head of the household is the one who defines the logic of the field and has been the promoter of a symbolic system regarding family relationships that justifies the authority they hold. ${ }^{34}$ Yet, the power they hold requires the complicity of the family for that power to be exercised, and it changes when circumstances change (for instance, with the emergence of the need to be cared for). The discourse adopted by family members shows that they find it difficult to hold this power in order to care for their elderly parents, as corroborated by Ayalon in previous studies. ${ }^{35} 36$

This change in power requires the will of the children to take it on and to negotiate, using their skills as 
leverage, especially when it comes to delivering care. Another aspect that is worth mentioning is the relationship between the legitimacy of the power of an agent and the possession of capital. In the relationship in which the activity of caring is established, the authority of the caregiver is more accepted if he or she has masculine characteristics from the perspective of some older people (eg, a working woman) or has a high level of education and access to information. Therefore, women incorporate behaviours that are linked to masculinity in order to exercise authority. The elderly individual maintains more control when the relative is a woman with a low level of education. ${ }^{36}$

This study found that there were two main approaches in the care of elderly individuals: traditional and modern. In many cases, the elderly individual's living status was a provisional one for the family, who attempted to establish support mechanisms that would allow the individual to live more safely with more care. In an Australian study by Crisp et $a l{ }^{36}$ which included 517 individuals aged 55-94 years, available resources, physical capacity, age, family support, opinions of the family and social network determined the permanence of the living status of an elderly individual who lived alone.

Female university graduates tended to hire help, and they tried to modify the home environment to make it more accessible and safer for their elderly family members. However, as reported by the present participants, introducing any change into their environment was a source of conflict between the elderly individual and their family. Furthermore, when it was clear that the elderly individual would not be able to continue living alone, a home for the elderly was considered as an alternative. Many families recognised that this resource was most likely to be chosen if the decision depended exclusively on them. For families, a home for the elderly meant being in a safe environment where all care is guaranteed, but they recognised that this generation of elderly individuals, particularly those who preferred to live alone, did not view the situation the same way. Instead, they viewed it as abandonment. This possibility often placed the family members in direct conflict with the elderly individual. For the latter, it meant leaving familiar surroundings, losing their ability to make their own decisions and leaving their life in the hands of others. Walker et $a l^{15}$ and Ayalon ${ }^{10}$ reported similar findings.

This study revealed that gender, age and family ties make up a system of social hierarchy with asymmetric power relationships. The principles on which an individual construct their social identity and the representations of the functions that correspond to each gender revolve around parents ${ }^{37}$; women with higher education reported that elderly individuals demanded less attention from caregivers who were male or who had a family of their own. Bourdieu ${ }^{34}$ suggested that gender differentiation structures the whole social life, favouring androcentric structures. The results of this study were not surprising considering the social representations that place females in the domestic domain and males in the public domain. Additionally, Adelantado $e t a l^{88}$ suggest that single women are viewed as survivors, with characteristics that enable them to persevere in this situation.

It is evident that the gender of the caregiver impacts the care provided. Women tend to intervene in problems at an earlier stage, whereas men wait and, if they can, delegate the caregiving tasks to women. Participants who were women believed that caregivers who were men were less emotionally involved, whereas participants who were men believed that caregivers who were women tended to magnify problems. Hiring services were viewed as a good option by participants who were men, who were usually less overprotective and tended to appreciate the freedom of the elderly individual more. ${ }^{30-32}$

In both female groups in the present study, the imprint of the traditional model that had marked them was clearly reflected. They viewed caregiving as a moral obligation. Female participants with basic or secondary education continued to assume the responsibility of caring for their elderly family members. They were often overburdened because they also had to care for the rest of the family and work outside the home. In contrast, women with more education had more resources and more socially recognised occupations. These women delegated a part of their caregiving responsibilities, although they continued to experience difficulties managing work and caregiving. Therefore, the two approaches coexisted, one from the more traditional perspective and the other from the more modern one, although both involved important costs for women. ${ }^{38} 39$

The family recognised the importance of the government's elderly care services in promoting their personal autonomy and care. However, they were critical of the existing resources and the bureaucracy involved in applying for those resources. Family members also considered the assessment process and the search for information too lengthy and fragmented. As pointed out by some authors, existing resources designed to aid the elderly who live alone are insufficient. ${ }^{39-41}$ Thereby, as confirmed by the participants, it is essential to offer necessary services to promote the independence of elderly individuals, to have flexible criteria to avail such services and easy access to the same. ${ }^{3142}$

Family members seemed to agree that no resource currently available in the offerings of services would improve the situation of elderly individuals living alone, as much as the company (and if possible, live-in company) of a hired individual. In this context, Bazo ${ }^{43}$ emphasised the importance of social policies to take into account the perspectives of the family, to avoid their desertion of the functions of care they still carry out and to stop putting pressure on families rather than on the government. Likewise, the present findings confirmed that, regardless of their level of education, gender and social class, family members preferred a model in which the state plays the main role in providing welfare, without this involving the rejection of the leading role of the family in the care of elderly individuals. ${ }^{11445}$ 
This study has some limitations with regard to the data collection techniques. Although the use of discussion groups is a qualitative technique that allows deeper understanding of the discourses of the participants, when selected by means of an advertisement, the participants may not fully represent the families of the elderly who live alone. Another limitation of the study was that the participants had not been chosen from different cultural groups, which may have changed the discourse. Finally, other sociodemographic characteristics of the participants that were not analysed in this study, such as age and economic status, may have been of interest.

\section{CONCLUSIONS}

For elderly individuals living alone, their own home provides them a sense of security and freedom, and it helps them retain their independence. However, this living situation may lead to conflict with other family members, whose support they need to be able to live alone. The changes in family members' roles pertaining to care and the resistance of elderly individuals to introducing changes into their environment and their way of living complicate the relationship between these elderly individuals and their families, with friction arising over matters related to care needs. Often, they need professionals to deal with these issues.

The results of this study reveal the importance of improving access to sociomedical resources to address all the needs of elderly individuals and their families. Specifically, these resources should match the needs of the population-including both families that have a more traditional view and those that have a more modern view-and reflect policies that promote gender equality.

The results of this study were compared with those obtained in other studies conducted in similar social, historical and cultural contexts. It was observed that family members of elderly individuals living alone describe the same limiting factors, though in different ways. Indeed, the care of elderly individuals poses a challenge to those in charge of sociomedical and social policies, their family members and the elderly individuals themselves. Adequate support should be provided at reasonable costs in order to maintain the quality of life and care of dependent elderly individuals and to meet the needs of their family members who, in our society, assume most of the responsibility of their care.

Acknowledgements The authors would like to thank the participants of this study for their effort and sincerity, and their elderly family members for opening the doors of their homes. References

Contributors JG-E and JM-M conceived and designed the experiments; JM-M and JG-E led the discussion groups; all authors analysed the data; AM-N contributed reagents/materials/analysis tools; JM-M and JG-E wrote the paper and reviewed and edited the manuscript.

Funding This study was funded by the Spanish Health Research Fund (Fondo de Investigación Sanitaria) of the Carlos III Health Institute, which reports to the Spanish Ministry of Economy and Competitiveness (PI09/90248).

Competing interests None declared.
Patient consent for publication Obtained.

Ethics approval The study protocol was also assessed and approved by the Research Commission and the Ethics Committee of the University of the Balearic Islands and the Clinical Research Ethics Committee of the Balearic Islands.

Provenance and peer review Not commissioned; externally peer reviewed.

Data sharing statement In a private database, the interviews and focal groups transcribed have been stored as personal information.

Open access This is an open access article distributed in accordance with the Creative Commons Attribution Non Commercial (CC BY-NC 4.0) license, which permits others to distribute, remix, adapt, build upon this work non-commercially, and license their derivative works on different terms, provided the original work is properly cited, appropriate credit is given, any changes made indicated, and the use is non-commercial. See: http://creativecommons.org/licenses/by-nc/4.0/.

\section{REFERENCES}

1. UN. Life tables obtained from World Population Prospects: The 2002 Revision. New York: United Nations Population Division, 2015.

2. EUROSTAT. Ageing characterizes the demographic perspectives of European societies. Belgium: Eurostat, 2016.

3. Eguren N. Familia y Estado: El reparto del bienestar [Family and State: The sharing of welfare]. Ábaco 2001, 29-30:101-12.

4. Ussel de Jl. El envejecimiento en España: situación actual y tendencias. Anales de la Real Academia de Ciencias Morales y Políticas 2015;92:51-74.

5. Bazo MT, Domínguez-Alcón C. Los cuidados familiares de salud en las personas ancianas y las políticas sociales [Family health care in the elderly and social policies]. Revista Española de Investigaciones sociológicas 1996;73:45-56.

6. Bover A. Cuidadores informales de salud del ambito domiciliario: Percepciones y estrategias de cuidado ligadas al género y a la generación [Informal home health care providers: Perceptions and care strategies linked to gender and generation]. Palma de Mallorca: Universidad de las Islas Baleares, 2004.

7. Martín C. et alLien familial et intégration. In: de Singly F, Martin C, Bertaux-Wiame I, Maruani M, Commaille J, . eds. La famille en question. Etat de la recherche. Paris: Syros, 1996:91-6.

8. Informa I. Las personas mayores en España [Older people in Spain]. Madrid: IMSERSO, 20142015.

9. Faria DF, Dauenhauer JA, Steitz DW. Fostering social work gerontological competencies: qualitative analysis of an intergenerational service-learning course. Gerontol Geriatr Educ 2010;31:92-113.

10. Ayalon L. Perceptions of old age and aging in the continuing care retirement community. Int Psychogeriatr 2015;27:611-20.

11. Esparza Catalán C, Abellán García A. Encuesta de Discapacidad, Autonomía personal y situaciones de Dependencia (EDAD 2008). Primeros resultados. Datos 2008 [Survey on Disability, Personal Autonomy and Dependency Situations (AGE 2008). First results. Data 2008. Madrid: INE, 2008.

12. Rosenmayr L, Koekeis E. Aging and society: An introduction to social gerontology (pp. 95-119). Williamson JB, Marriage, family and friendships. New York: Rinehart \& Winston, 1963.

13. Wilson G. I am the eyes and she arms: changes in gender roles in advanced age. In: Arbes S, Ginn J, eds. Relationship between gender and aging: Sociological approach. Madrid: Nancea, 1996:141-62.

14. Walker A. A European perspective on quality of life in old age. Eur $J$ Ageing 2005;2:2-12.

15. Walker J, Crotty BH, O'Brien J, et al. Addressing the Challenges of Aging: How Elders and Their Care Partners Seek Information. Gerontologist 2017;57:955-62.

16. Kivnick HQ. Living Gerontology: Providing Long-Distance, Long-term Care. Gerontologist 2017;57:54-60.

17. Bourdieu P. Capital, cultural, escuela y espacio social [Cultural Capital, school and social space]. Madrid: Siglo, 1997.

18. Guba EG, Lincoln S. Paradigmatic controversies, contradiction and emerging confluences. In: Denzin NK, Lincoln YS, The Sage Handbook of Qualitative research. 3th edn. Thousand Oaks: Sage, 2005:191-215.

19. Bourdieu P. Intelectuales, política y poder. 129. Eudeba: Buenos Aires, 1999.

20. Potter J, Wetherell M. Discourse and Social Psychology: Beyond Attitudes and Behaviour. Potter J, Two kinds of natural, Discourse Studies. 4. London: Sage, 1987:539-42.

21. Gómez R, Flores G, Gil J, et al. Aspectos básicos sobre el análisis de datos cualitativos, cap.11 En: Metodología de la investigación 
cualitativa: Ediciones Aljibe, Archidona, Málaga, España, 2004:197-218.

22. Hallett CE, Austin L, Caress A, et al. Community nurses' perceptions of patient 'compliance' in wound care: a discourse analysis. J Adv Nurs 2000;32:115-23.

23. Schiffrin D. Approaches to Discourse: Language as Social Interaction. NYC: Wiley, 1994.

24. Fiske ST. "Stereotyping, prejudice, and discrimination". Handbook of social psychology. 4th edn. New York: McGraw-Hill, 1994:357-411.

25. Alvarez-Gayou J. Cómo hacer investigación cualitativa: Fundamentos y Metodología. México: Paidós, 2003.

26. Miles M, Huberman AM. Data management and analysis methods. In: Denzin NK, Lincoln YS, eds. Handbook of qualitative research. London: Sage Publication, 1994:429-44.

27. Morse JM. Myth \#93: Reliability and validity are not relevant to qualitative inquiry. Qualitative Health Research 1999;9:717.

28. Fericgla JM. Envejecer, una antropología de la ancianidad. Barcelona: Empresa Editorial Herder, SA, 2002.

29. Gil Calvo E. El miedo es el mensaje: Riesgo, incertidumbre y medios de comunicación. Madrid: Alianza, 2003:320.

30. Pérez Ortiz L. Envejecer en femenino. Las mujeres mayores en España a comienzos del siglo XXI [Aging in female Older women in Spain at the beginning of the 21st century]. Madrid: IMSERSO. Instituto de la mujer, 2004.

31. López Doblas JL. Personas mayores viviendo solas. La autonomía como valor en alza [Older people living alone. Autonomy as a rising value]. Madrid: IMSERSO, 2005.

32. Boldy D, Grenade L, Lewin G, et al. Older people's decisions regarding 'ageing in place': a Western Australian case study. Australas J Ageing 2011;30:136-42.

33. Bourgeois MS, Camp C, Rose M, et al. A comparison of training strategies to enhance use of external aids by persons with dementia. J Commun Disord 2003;36:361-78.

34. Bourdieu P. La dominación masculine [Male domination]. Anagrama: Barcelona, 2000.

35. Ayalon L. Intergenerational Perspectives on Autonomy Following a Transition to a Continuing Care Retirement Community. Res Aging 2016;38:127-49.
36. Crisp DA, Windsor TD, Butterworth P, et al. What are older adults seeking? Factors encouraging or discouraging retirement village living. Australas J Ageing 2013;32:163-70.

37. Bourdieu P. El sentido práctico [Practicality]. Taurus: Madrid, 1991.

38. Adelantado F, Segura C, De Andrés J, et al. Los mayores de 85 años en Sabadell [The older than 85 years old in Sabadell]. Revista Multidisciplinar Gerontología 2004;14:271-8.

39. Bazo MT, Ancizu I. El papel de la familia y los servicios en el mantenimiento de la autonomía de las personas mayores: Una perspectiva internacional comparada [The Role of the Family and Services in Maintaining the Autonomy of the Elderly: A Comparative International Perspective]. Revista Española de Investigaciones Sociológicas 2004;105:43-77.

40. Compán Vázquez D, Sánchez González D, desván Lancianosal. El proceso de degradación biológica y social de la población mayor en el municipio de Granada [The elders to the attic. The process of biological and social degradation of the elderly population in the municipality of Granada]. Cuadernos Geográficos. Granada 2005;36:255-74.

41. Beaver M, Miller DA. La práctica clínica del trabajo social con las personas mayors [The clinical practice of social work with the elderly. Barcelona: Paidós, 1998.

42. Puga MD. La dependencia de las personas con discapacidad: Entre lo sanitario y lo social, entre lo privado y lo public [The dependence of people with disabilities: Between health and social, between private and public]. Revista Española de Salud Pública 2005;79:327-30.

43. Bazo MT. Personas mayores y solidaridad familiar [Older people and family solidarity]. Política y Sociedad 2008;45:73-85.

44. Arriba A, Calzada I, del Pino E. Las actitudes de los españoles hacia el Estado de Bienestar, 1985-2005 [The Attitudes of the Spaniards towards the State of Welfare, 1985-2005]. Serie Opiniones y Actitudes. Madrid: CIS, 2006.

45. Castejón Villarejo P, Esparza Catalán C, García A. et alASalud dependencia y cuidados [Health, dependence and care]. In: Abellán García A, Del Barrio Truchado E, Castejón Villarejo P, Esparza Catalán C, Fernández-Mayoral Fernández G, Pérez Ortiz L, Puga González MD, Rojo Pérez F, Sancho Castiello M, . eds. A propósito de las condiciones de vida de las personas mayores [Concerning the living conditions of the elderly] (pp. 67-82). Madrid: IMSERSO, 2007. 